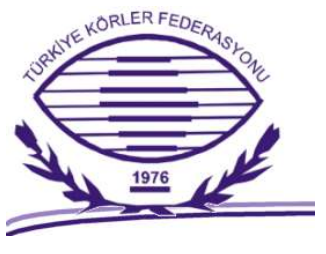

Özgün Makale (Olgu Sunumu)

\title{
Unique Article (Case Report)
}

Geliş Tarihi - Submitted: 17.12.2021

Kabul Tarihi - Accepted: 30.12.2021

Atıf Bilgisi / Reference Information

Arıcı, A., Bolat, G. B. \& Artan, T. (2021). Sosyal hizmet uygulamalarında en sık karşılaşılan etik ikilemler: gizlilik-raporlama ve özerklik-paternalizm. Ufkun Ötesi Bilim Dergisi, 21 (2), 317337.

Doi: https://doi.org/10.54961/uobild.1038120

\section{SOSYAL HIZMET UYGULAMALARINDA EN SIK KARŞILAŞILAN ETIK IKILEMLER: GIZLILIKK-RAPORLAMA VE ÖZERKLIK-PATERNALIZM}

\section{Aylin ARICI ${ }^{1}$}

\section{Gizem Burcu BOLAT²}

Taner ARTAN ${ }^{3}$

\section{ÖZET}

Amaç: Bu çalışmanın amacı sosyal hizmette etik muhakeme çerçevesinde en sık karşılaşılan çatışma durumlarından gizlilik-raporlama ile özerklik-paternalizm ikilemlerini açıklamak ve konuyu olgu örneği üzerinden ele alarak sosyal hizmet uygulamalarında çelişki yaratan etik ikilem durumlarının çözümlenmesine ilişkin alternatif öneriler sunmaktır. Olgu: Çalışmada olgu olarak; çocuk işçiliği, çocuk inmal/istismarı ve aile içi şiddet öyküsü bulunan dört çocuklu bir aile ele alınmıştır. Baba, büyük iki erkek çocuğu sokakta çalışmaya zorlamıştır. Çalıştırılan çocuklar, ablanın inbarı üzerine kuruma yerleştirilmiştir. Baba, çocuklarına ve eşine şiddet

\footnotetext{
${ }^{1}$ Arş. Gör. İstanbul Üniversitesi-Cerrahpaşa Sağlık Bilimleri Fakültesi, Sosyal Hizmet Bölümü, e-posta: aylin.a_@hotmail.com, ORCID: 0000-0003-3872-2984

${ }^{2}$ Sosyal Hizmet Bilim Uzmanı, e-posta: bolatgizemburcu@gmail.com, ORCID: 0000-0002-2442-5658 (iletişim y.)

${ }^{3}$ Doç. Dr. İstanbul Üniversitesi-Cerrahpaşa Sağlık Bilimleri Fakültesi, Sosyal Hizmet Bölümü, e-posta: taner.artan@iüc.edu.tr, ORCID: 0000-0002-8716-2090
} 
uygulamaktadır. Anne, eşinden şiddet gördüğü gerekçesiyle akrabasının yanına sığındıysa da bir süre sonra tekrar eşinin yanına dönmüştür. Olgu değerlendirme sürecinde aile yeniden bir arada olmak istediğini bildirmiştir. Ayrıca kuruma yerleştirilen çocuklardan biri de tekrar ailenin yanına dönmek istemektedir. Olguda çalışan sosyal hizmet uzmanı, özerklik-paternalizm ikilemiyle karşı karşıyadır. Sonuç: Olgu yönetim sürecinde müdahale yöntemleri planlanırken özerklik-paternalizm ikilemiyle karşılaşılmış, eylemlerde müracaatçının özerkliği prensibi baskın olmakla birlikte yararlandırma ilkesi çerçevesinde de uygulamalar yürütülmüştür. Bazı kararlar alınırken, karşılaşılan çatışma durumunun üçüncü bir yol gösterici değer olan kendi kaderini tayin hakkı çerçevesinde çözümlenmesi sağlanmıştır.

Anahtar Kelimeler: Sosyal Hizmet, Etik Ikilem, Gizlilik, Raporlama, Özerklik, Paternalizm

\section{MOST FREQUENT ETHICAL DILEMMAS IN SOCIAL WORK PRACTICES: CONFIDENTIALITY-REPORTING AND AUTONOMY-PATERNALISM}

\section{ABSTRACT}

Purpose: The aim of this study is to explain the dilemmas of confidentiality-reporting and autonomy-paternalism, which are the most common conflict situations within the framework of ethical reasoning in social work, and to offer alternative suggestions for resolving ethical dilemmas that create conflict in social work practices by considering the issue through case studies. Case: As a case in the study; A family with four children with a history of child labour, child neglect/abuse and domestic violence is discussed. The father forced the two older boys to work on the street. The children who were employed were placed in the institution upon the notice of the sister. The father is abusive to his children and his wife. Although the mother took refuge with her relative on the grounds that she was subjected to violence by her husband, she returned to her husband after a while. During the case evaluation process, the family stated that they wanted to be together again. In addition, one of the children placed in the institution wants to return to the family again. The social worker working on the case is faced with the autonomy-paternalism dilemma. Conclusion: While the intervention methods were planned in the case management process, the autonomy-paternalism dilemma was encountered. While taking some decisions, it was ensured that the conflict 
situation encountered was resolved within the framework of a third guiding value, the right to self-determination.

Keywords: Social Work, Ethical Dilemma, Confidentiality, Reporting, Autonomy, Paternalism

\section{GíRiş}

Etik belirsizliklerle hayatın her alanında karşılaşılabilir. Bu belirsizlikler kişileri, özellikle profesyonel meslek alanlarında eylemlere ilişkin karar verme aşamasında içinden çıkılması güç ikilemlerle karşı karşıya bırakabilir. Sosyal hizmete ilişkin etik konular ve ikilemler, piyasa odaklı stratejiler yoluyla sosyal hayatı şekillendiren küreselleşme sürecindeki derin sosyal, politik ve kültürel dönüşümler altında meydana gelen süreci yansıtır (Zaviršek, Rommelspacher, \& Staub-Bernasconi, 2010). Öyle ki, Zygmunt Bauman'ın da belirttiği gibi, hayat giderek daha güvencesiz ve belirsiz hale gelmektedir (Bauman, 2007). Zenginler ve yoksullar arasında büyüyen eşitsizliklerin ve kutuplaşmanın arttığını söylemek elbette yeni bir şey değildir. Fakat toplumların ve kültürlerin yeniden uyarlanması; güçlü dini duyguların ve kültürel çatışmaların ortaya çıkmasına, devlet otoritesinin yeniden yapılandırılmasına ve her zaman var olan neoliberal ideolojiler ise sosyal, politik ve ekonomik yaşamı bütünüyle kapsayan kaygılara zemin hazırlamaktadır (Zaviršek ve ark., 2010). Dolayısıyla, dünyanın değişen dinamikleri, tüm disiplinlerin çalışma yöntemlerini ve karşılaştıkları olgu çeşitliliği ile etik değerlendirmelerini etkilediği gibi en temel amacı sosyal adaleti sağlayacak çalışmalar yapmak olan sosyal hizmet mesleği de bu durumdan etkilenmiştir.

NASW (National Association of Social Workers) tarafından hazırlanan ve sosyal hizmet uygulamalarında etik standartların kapsamlı bir kılavuzu olan ilke ve değerler, etik ya da profesyonel davranış için temel bir çerçeve sağlar (Sasson, 2008). Etik ilkeler ışığında belirlenen; müracaatçının kendi kaderini tayin hakkı, bilgilendirilmiş onam, mesleki yeterlilik, kültürel yeterlilik/sosyal çeşitlilik, çıkar çatışması, mahremiyet ve gizlilik taahhütleri, uygulamalar esnasında sosyal hizmet uzmanına yol gösterici nitelik taşımaları açısından oldukça önemlidir. Etik standartlar; çatışan mesleki görevler, değerler veya çıkarlar karşısında da sosyal hizmet uzmanına yardımcı olabilir. Belirlenen etik kurallarının nihai amacı, kabul edilebilir ve kabul edilemez nitelikteki davranışları belirleyerek mesleki dürüstlüğü arttırmaktır (Reamer, 1997). Bireysel ve 
toplumsal refahı artırmayı hedefleyen sosyal hizmet uzmanları, mesleki uygulamalar esnasında birçok etik ikilemle karşılaşmaktadır ve etik ikilem durumlarının etik değerler ışığında çözülmesi beklenir (Çiftçi \& Gönen, 2011).

Etik ikilem, sosyal hizmet uzmanının iki veya daha fazla sayıda çelişkili etik yönerge arasından seçim yapması gereken durumlarda veya her alternatifin bir veya daha fazla kişi için istenmeyen bir sonuç verdiği durumlarda ortaya çıkar ve birbirini etkileyebilen en az iki karşıt değerin çatışması, etik ikilem olarak değerlendirilir (Erkoç \& Lofti, 2021). Etik ikilem, çatışmanın tarafları arasındaki kişilerarası bağlantıların bir sonucudur. Sosyal hizmet uzmanı için etik ikilem, yapılacak en etkili uygulamaya değil, koşullar altında yapılacak doğru uygulamaya dayanır. Levy (1976), uygulama sırasında görev ve yükümlülük temelinde yapılan eylemin sonucunu düşünmenin, etik sorumluluğun önemli bir parçası olduğunu belirtmektedir. Sosyal hizmet uzmanları, sosyal hizmet mesleğine atfedilen değerlere ve etik değerlere bağlı kalmayı taahhüt eder. Bu etik değerler nadiren de olsa sosyal hizmet uzmanında çatışma yaratabilir. İki çelişkili değerin varı̆̆ı, karmaşık ve dikkatli bir analiz gerektiren etik bir ikilem yaratır. Uygulamada ortaya çıkan etik sorunlar, çoğu zaman çatışan çıkarlara bağlı kalmaksızın çözülemez. Bu, belirli bir etik ilkeye daha fazla değer verilmesini gerektirir ve kişinin ek çıkarlarından yoksun bırakılmasına neden olabilir. Etik ikilem hem faydacı $^{4}$ hem de deontolojik ${ }^{5}$ teorilerle açıklanabilir. Bu noktada sosyal hizmet uzmanı, yalnızca müracaatçının çıkarlarını ve refahını artıracak doğru kararı vermeyi amaçlamalıdır (Sasson, 2008).

Barker'a göre problemlerin en aza indirilmesi veya ortadan kaldırılması, çatışmaların çözümlenmesi ile mümkündür (akt. Çiftçi \& Gönen, 2011). Uzmanlar genellikle müracaatçı ile alternatif çözümler yaratma, eğitme, aydınlatma, arabuluculuk, uzlaşma konularında çalışır (Çiftçi \& Gönen, 2011). Loewenberg ve Dolgoff (1996)'a göre sosyal hizmet uygulamalarının yaşayabileceği etik ikilemin; rakip değerler, rakip bağlılıklar ve belirsizlikler olmak üzere üç ana sebebi vardır. Minahan'a göre ise sosyal hizmet

\footnotetext{
${ }^{4}$ Faydacı Teoriler: Faydacı etik prensibine dayanır. Bu prensibe göre bir eylem sonuçlarından bağımsız olarak düşünülemez. Eğer eylemin sonuçları kişiye fayda sağlıyorsa, o eylem doğrudur (Türer \& Aydın, 2019).

${ }^{5}$ Deontolojik Teoriler: Deontolojik etik görüşüne dayanır. Bu prensip doğru eylemlerin, sonuçlarla ilgili olduğunu reddeder. Buna göre bir eylem yalnızca başlangıç noktası olan moral kural, ilke ve ödeve uygun olduğu taktirde doğrudur. Dolayısıyla eylemin ortaya çıkardığı sonuçlar, eylemin doğruluğunu etkilemez (Özateş, 2010).
} 
uzmanlarının etik ikilemleri yedi temel alana ayrılır. Bunlar şu şekilde sıralanmaktadır (akt. Çiftçi \& Gönen, 2011);

- Gizlilik ve gizli bilgi,

- Doğru söyleme,

- Biri tarafından kararın verilmesi veya kendi kaderini belirleme,

- Yasalar, kurallar, düzenlemeler, politikalar,

- Bir meslektaşı üzerinde baskı kurma,

- Sınırlı kaynakların dağıtımı,

- Bireysel ve mesleki değerler.

Bu bağlamda çalışmada, bir olgu üzerinde çalışırken sosyal hizmet uzmanlarının düşünme biçimlerini ve eylemlerini şekillendirmelerinde kritik bir öneme sahip olan etik muhakeme sürecine değinilecek, sosyal hizmet uygulamalarında en sık karşılaşılan gizlilik-raporlama ile özerklik- paternalizm etik iklimleri açıklanacak ve ardından konu, bir olgu örneği üzerinden değerlendirilecektir.

\section{Etik Muhakeme}

Sosyal hizmet eğitiminin bir parçası, karar verme sürecine ilişkin değerlendirme yapabilme becerisi kazanmaktır (Çiftçi \& Gönen, 2011). Sosyal hizmet müdahalesi esnasında müracaatçının yaşamsal ve toplumsal ihtiyaçlarını karşılamak için kaynaklarla buluşmasına yardım eden uzman, karşısına çıkacak etik ikilemleri bilgi beceri- değer temelinde ele almak durumundadır. "Değer" temeli, uzmanın uygulamalarında kişisel ve mesleki değerlerde bir çatışma olması durumunda uygulamaya etik ilkelere göre yön vermesini ifade eder (Koç, 2015).

Sosyal hizmette etik muhakeme, sadece bazı ahlaki değerlere bağlılığı ifade etmez. Etik standartlar ile ideal uygulamalara vurgu yapmaktan ve profesyonel kararları vicdani yükümlülüklerle uzlaştırmaktan daha fazlasını içerir. Diğer bir ifadeyle sosyal hizmet uzmanları mesleki uygulamalar gereği hukuka uygun olarak müracaatçıların kişisel alanlarına müdahale edebilir. Müdahaleleri planlarken en doğru yöntemi bulmak için hak temelli anlayış doğrultusunda her bir müracaatçının; toplumsal işlevselliğinin artırılması, kendini gerçekleştirme dinamiklerini tehdit eden unsurların ortadan kaldırılması ve sivil ya da kamusal alanda görünür kılınarak toplumla bütünleşmesinin sağlanması ideallerini göz önünde bulundurur. Bu durum, her müdahalenin sadece bilimsel bilgi ya da profesyonel yöntemlere değil aynı zamanda etik açıdan da 
uygunluğu temin edilmiş bir karara dayandırııması gerektiği anlamına gelir. Dolayısıyla etik kararlar, şiddetli çatışmaların ve ikilemlerin çözülmesini gerektiren karmaşık süreçler içerir. Müracaatçı, uzman için önemli olan değerlerden çok daha farklı ahlaki normları benimsemiş olabilir ya da yıkıcı ve ihlal edici uygulamalarda ısrar edebilir. Veyahut kanunlarla belirlenen kurallar bazı müracaatçılar için adil olmayabilir ve sosyal hizmet kurumları, müracaatçılarının ihtiyaçları ile sistem üzerinde ekonomik açıdan yük olabilecek uygulamalar gerçekleştirmek durumunda kalabilir. Böyle bir durumda sosyal hizmette etik muhakeme, mesleki kararları yansıtmak için teorik bir arka plana ve şeffaf kriterlere intiyaç duyar. Bu noktada sosyal hizmet uzmanının etik muhakeme sürecinde karar için bir gerekçe ararken siyasi ve ahlaki bilimsel bilgi ile gündelik koşullar arasında denge kurmaya çalışması önem kazanmaktadır (Grossmanns, 2010).

Bazı ülkelerin siyasi ve sosyal sistemleri diğerlerinden belli noktalarda ayrışabilmektedir. Bu nedenle nadiren de olsa yaşamın bazı alanlarında diğerlerinden farklı olağandışı etik ikilemlerle karşılaşılabilmektedir. Ancak çoğu zaman sosyal hizmet değerlerine bağılık, kültürler ve coğrafi sınırların üstünde bir noktadadır. Dolayısıyla etik ikilemler yaratan temel değer çatışmalarının her ülkede büyük oranda benzerlik gösterdiğini söylemek mümkündür. Bu doğrultuda diğer ülkelerin etik ikilem alanındaki uygulamaları örnek alınabilir. Elbette bu hipotezin doğruluğu ancak sosyal hizmet uzmanlarıyla yaşanılan etik ikilem türlerine ilişkin uluslararası düzeyde araştırmalarla tam olarak anlaşılabilir (Linzer, Conboy, \& Ain, 2003).

Etik muhakeme esnasında eleştirel düşünme becerisi son derece önemlidir. Eleştirel düşünme, kişinin pratiğini ve bilgisini sorgulamaya devam ettiği süreci ifade eder. Bir olgu üzerine düşünürken etik kuralları göz önünde bulundurmak; müracaatçının kendi kaderini tayin hakkına saygı duyma ve insanların potansiyellerine ulaşmalarına yardımcı olma idealleri açısından son derece önemlidir (Moorhead \& Johnson, 2010).

Etik ikilemi değerlendirme ve keşfetme süreci, çözüm odaklı yaklaşımın sosyal hizmet değerleri ve etiği ile ne kadar uyumlu olduğunu ortaya çıkarmıştır. Çünkü her iki yaklaşım da kendi kaderini tayin etmeye, müracaatçıyı güçlendirmeye ve müracaatçının bulunduğu yerden başlamaya inanır. Dahası birbirini tamamlayan çerçevelerde çalışmak bir uzman için çok daha kolaydır (Moorhead \& Johnson, 2010). Etik ikilemler konusunda kullanılan etkili yöntemlerden diğeri kanıta dayalı uygulamadır (KDU). Kanıta dayalı uygulama; alışılan paradigmalarda değişimi, bilgi, pratik, 
araştırma, sosyal hizmet eğitimi ile politikasına dair yeni bir düşünme biçimini öngörmektedir (Maynard, 2007). Gibs, kanıta dayalı uygulamayı yalnızca bir müdahale yöntemi değil yaşam boyu devam eden bir süreç olarak tanımlamıştır (akt. Özkan \& Çifçi). Bununla birlikte kanıt dayalı uygulamanın benimsenmesi birtakım zorluklar ve sınırlamalar barındırır. Ancak bu yöntem getirdiği çözümler ile dikkate değerdir. Çünkü bir sosyal hizmet uzmanının kanıta dayalı uygulamayı benimsemesi; etik yükümlülükleri yerine getirmesine yardımcı olacak yönerge ve ilkeler sağlamanın yanı sıra uzmanın bilgi birikimini artırmasına ve müracaatçılarının münferit özellikleri ile değer ve koşullarının farkına vararak bunlara duyarlı yollarla etkili uygulamalar geliştirmesine zemin hazırlayacaktır. Kısacası kanıta dayalı uygulama, kanıta dayalı uygulamadan en çok yararlanacak kişiler olan müracaatçılara daha etkin bir şekilde yardımcı olmak için elverişli bir ortam yaratacaktır. Dolayısıyla kanıta dayalı uygulama ile; müracaatçıların kişisel özelliklerine ve koşullarına duyarlı etik uygulamalar ve ilkeler sunarak, yol gösterici nitelikte bilgilere ulaşılabilir. Kanıta dayalı uygulama planlanırken sorulması gereken sorular şunlardır (akt. Maynard, 2007):

(1) Problem formülasyonunun altında hangi değerler yatmaktadır?

(2) Problem formülasyonu hangi olası çözümlere yol açacaktır?

(3) Bu problem formülasyonu neden önemlidir?

(4) Müracaatçı kimdir ve araştırma müracaatçıya nasıl yardımcı olabilir?

(5) Problem formülasyonunun altında yatan ontolojik ve epistemolojik varsayımlar nelerdir?

(6) Hangi önyargılar belirgindir?

(7) Önyargılar nasıl düzenlenebilir?

Kanıta dayalı uygulama ile ortaya atılan soruları cevaplamak kolay olmayabilir ancak KDU hareketinin araştırma, uygulama ve eğitim tartışmaları ile konuyu eleştirel perspektifle ele alması, kuşkusuz ne yapıldığı ve nasıl yapıldığı konusundaki farkındalığı artıracaktır (Maynard, 2007).

Etik ikilemler, bazı zamanlar alanda deneyimli bir uzman için bile çözülmesi zor bir hal alabiliyorken, yeni mezun bir uzman için çözüm çok daha karmaşıktır. Bu noktada süpervizyon, etik ikilemin aşılması ve gerekli müdahaleleri destekleyen değerlere ilişkin bir çerçeve sunabilir. Özellikle sosyal hizmet eylemlerinde bulunan yeni 
mezunların, deneyim eksikliğinin göz önünde bulundurulması gerekir. Dolayısıyla bir sosyal hizmet uzmanının, bir süpervizörün deneyiminden yararlanması, karşılaşılan etik sorunların değerlendirilmesi ve çözüme kavuşturulması açısından hayati niteliktedir (Moorhead \& Johnson, 2010).

\section{Gizlilik ve Rapor Etme Zorunluluğu İkilemi}

Literatür, gizlilik taahhüdü doğrultusunda müracaatçıların mahremiyet haklarını korumaya çalışan mesleki etik kurallar ile rapor etmeyi zorunlu tutan yasal yetki arasındaki ikileme odaklanmaktadır. Bu ikilem temelde şudur: gizliliği ihlal etmek etik değildir; bildirmemekse yasa dışıdır. Örneğin bir müracaatçının gizlilik haklarının korunması ile yasal zorunluluğu olan çocuk istismarını bildirme yükümlülüğü arasında kalan sosyal hizmet uzmanı, bir ikilemle karşı karşıyadır. Bu konuya ilişkin ruh sağlığı alanında çalışan profesyonellere yönelik araştırmalar yapılmaktadır; ancak yapılan çalışmalar, bu alanın dışında çalışan profesyonellere yönelik literatürün eksik olduğunu ortaya çıkarmıştır. Örneğin Amerika'da bir bölgede araştırmacılar, bölge avukatlarınca verilen gizlilik kararını ihlal etmek istemeyip, mahkemenin talep ettiği bilgileri vermeyi reddettikleri için mahkemeye saygısızlıktan hapsedilmişlerdir. Bu tarz örnekler olsa da sosyal bilimler içinde, mesleki etik kuralların yasa ile çatıştığı pek çok davada araştırmacılar çok sayıda emsal karar çıkarmışlardır (Farberman, Fınch, \& Bergman, 1997).

Amerika Birleşik Devletleri'ndeki her bir eyalette; gerçek, şüpheli ya da çocuk istismarı potansiyeli taşıyan olguları yerel bir raporlama kurumuna bildirmesi yasalarca zorunlu kılınan belirlenmiş meslek grupları ve profesyoneller bulunmaktadır. Bu profesyoneller, sıklıkla bir tür terapötik ilişkiye dahil olan kişilerle doğrudan temas halindedir. Eyalet yasaları, küçük fakat önemli bazı tanımlarda ve raporlama gereklilikleri açısından farklılık gösterse de tamamı 1974 tarihli Çocuk İstismarını Önleme ve Tedavi Yasası'nda belirlenen zorunlu raporlamaya ilişkin federal standartları yansıtır ve çocuk istismarını iyi niyetle bildiren kişilere yasal dokunulmazlık verir. Yasanın özü, kişileri yanlışlık olsa bile çocuk istismarı inbarı yapma konusunda teşvik etmektir (Farberman ve ark., 1997).

1998 tarihli ulusal bir araştırmada İsrailli sosyal hizmet uzmanlarının en sık karşılaştıkları etik ikilemin "gizlilik" olduğu ortaya çıkmıştır. Araştırma sonuçlarına göre uzmanlar özellikle; kamu kurumlarını bilgilendirme ve uyarma görevi de dahil olmak üzere müracaatçıların iletişim bilgilerinin korunmasını sınırlamaları, çocuk ve aile 
ikilemleri, aydınlatılmış onam belirsizliklerine karşı; bilgisayar ve teknoloji kullanımı söz konusu olduğunda gizlilik ihlallerinin önlenmesini, müracaatçının kendi kaderini tayin hakkının teşvik edilmesini, özellikle danışanın onuruna saygı duyulmasını önemsemişlerdir. Uzmanlar böyle durumlarda kendi danışmanlarına, meslektaşlarına, süpervizörün tavsiyelerine ve rehberlik için mesleki etik kurallara dikkat ettiklerini ifade etmişlerdir. Ancak İsrail'de ABD'den farklı olarak hizmetlerin çoğu, devlet tarafından finanse edilmektedir. İsrail'de özel uygulama minimum seviyededir. Bu nedenle uygulamalarda bazı sorunlar ortaya çıkmaktadır. Araştırmadaki tespitlerden bir diğeri ise şudur: Bazı uzmanlar söz konusu ikilemi, önemli pozisyondaki bir başkasına ya da arkadaşına danışmaktadır. Oysa gizliliği korumak ve mesleki standartları yükseltmek için müracaatçıyla ilgili bilgileri eş ve arkadaşlarla paylaşmak doğru değildir. İş deneyimine ilişkin bu etik ilke, kişilerarası ilişkilerde sorunlar yaratabilmektedir. Çünkü açık iletişim arkadaşlıkların ve evliliklerin temel taşıdır. Ortaya çıkan bu konu ile ilgili dikkatli çalışma ve standarda intiyaç duyulmaktadır (Linzer ve ark., 2003).

İsrail'de yapılan araştırma uzmanların gerçekleştirdikleri sosyal hizmet müdahalelerinde genel anlamda; gizlilik, kendi kaderini tayin ve müracaatçının onuru ve değeri konularına büyük önem verdiklerini ortaya koymuştur. Çalışma aynı zamanda uzmanların doğru ve iyi olanı yapmak için içsel motivasyona sahip olduklarını göstermiştir. İsrailli uzmanlar; bu alanda faaliyet gösteren profesyonellere bazı öneriler sunmuşlardır: Bunlar (Linzer ve ark., 2003);

1) Günlük etik ikilemlerle nasıl başa çıkılacağı ile ilgili küçük ya da büyük ölçekte araştırmalarla temel bir çerçeve oluşturmaya ve uygulamaya devam etmek, öğrencilere de etik ikilemler konusunda bilgi ve deneyim kazandırmak gerekmektedir.

2) Etik ikilemler konusuna sosyal hizmet eğitiminde olduğundan daha fazla yer verilmelidir. Özellikle en sık karşılaşılan; gizlilik, uyarma görevi, bağlantı kurulan müracaatçı sayısı, uygulayıcının yeterliliği, bilgilendirilmiş onam ve doğruyu söyleme ikilemlerine zaman ayırılması gerekmektedir.

3) Daha fazla hizmet içi eğitim ve süpervizyon, etik ikilemlerin çözülmesinde uzmanlara kolaylık sağlayacaktır.

4) Uzmanların eşleri ve yakın çevreleri ile deneyimlerini paylaşarak iletişimlerini güçlendirirken, müracaatçıların gizliliğinin de sağlanması için hassas yollar keşfedilmelidir. 
5) Etik konusuna odaklanan daha fazla konferans ve halka açık formlar oluşturulmalıdır. Sosyal hizmet mesleği içindeki gizliliğe ilişkin, sosyal hizmet ve diğer meslekler arasında, sosyal hizmet ve hükümet kuruluşları arasında resmi ve resmi olmayan diyaloglar artırılmalıdır.

\section{Özerklik ve Paternalizm İkilemi}

Müracaatçının -kendisi için zararlı olsa bile- özerk davranışlarda bulunma hakkı ile sosyal hizmet uzmanının faydayı artırma ve zararı önleme yükümlülüğü arasında uygun bir denge var mıdır? Müracaatçının kendi hedeflerini belirleme ve hata yapma hakkına inananlar ile danışanın yalnızca kendi isteklerine bakılmaksızın, mesleki tavsiyeleri izleyerek bilinçli seçimler yapması gerektiğine inananlar arasındaki gerilim uzlaşma ile sonuçlanabilir mi? Felix Biestek, bu gerilimi "kendi kaderini tayin hakkı" yani olgu çalışmalarında müracaatçının kendi kararlarını verme hürriyetinin pratikteki hali şeklinde tanımlamıştır (akt. Abramson, 1985). Sosyal hizmet uzmanlarının; müracaatçıların mevcut kaynakları görmesine ve kullanmasına yardımcı olarak bu hakka saygı duyma, intiyacı tanıma, toplum ve kişiyi harekete geçirme noktasında yönlendirici olma görevleri bulunmaktadır. Bununla birlikte, müracaatçının kendi kaderini tayin hakkı ile olumlu ve yapıcı karar verme kapasitesi; hukuki çerçeve ve kurumun işlevleri ile sınırlandırılmıştır. Müracaatçının özerkliği ile yararlandırma prensibi arasındaki gerilim; negatif özgürlük, müracaatçının özerklik hakkı ve pozitif özgürlük, yani bir müracaatçının refahını koruyacak ve onun gelecekte anlamlı hedefler peşinde koşma yeteneğini artıracak uygulamalar arasındaki çatışmayı dengelemenin bir yolu olup olmadığının belirlenmesiyle çözülebilir. Uzman; gerekli bilgilendirmeyi, alternatif yolları ve uygulamaları müracaatçıya aktardıktan sonra müracaatçının nihai seçimi farklıysa, onu terk etmeden geri adım atabilir ve müracaatçının seçim yapmasına izin verebilir mi? Uzman; müracaatçının özgür kararının onu, onaylamadığı ve onun için zararlı olabileceğini düşündüğü bir yöne götürdüğünde bile sorumluluk ve bağlılık duygusunu koruyabilir mi? Bu durum, uzman için müracaatçı adına anlamlı bir eylem olasılığına dönüşen özerklik hakkı ve yararlandırma prensiplerini birleştirme yeteneğinin gerçek sınavıdır (Abramson, 1985).

Özerklik kavramı temelde, başkaları tarafından kontrol edilmekten ve anlamlı seçimi engelleyen kişisel sınırlamalardan bağımsız olan benliğin üstünlüğünü ifade etmektedir. Bir seçimin gerçek olabilmesi ise onun çaresizce değil, özgürce seçilmiş olmasına bağlıdır. Dolayısıyla kişinin seçimleri, inceleme ve değerlendirmeye açık 
olmalıdır. Moody (1998), yaşılıarın özerkliğine yönelik kaygının, onların haysiyetine yönelik kaygıya dayanması gerektiğini savunmaktadır. Haysiyet etiğine yönelik duyarlılık; profesyonellerin, yaşamın son evrelerinde bulunan insanları tedavi ederken karşılaşııları trajik seçimlerle yüzleşmelerini sağlayacaktır. Haysiyet etiği özerkliği ve aynı zamanda yararılıı̆ı destekleyebilir. Beauchamp ve Childress (2001), yararlanma ilkesini bireylerin çıkarlarını artırmalarına yardımcı olma yükümlülüğü olarak görmektedir.

Yararlıı̆ın birinci ilkesi, insanlara yarar sağlanmasını; ikincisi ise yarar ve zararın dengelenmesini gerektirir. Fayda üretme sürecinde birtakım riskler de ortaya çıktığı için, faydaya dayalı ikinci ilke, olumlu fayda ilkesine önemli bir ektir. Ruh sağlığı meslek profesyonellerinin; kişilerin, bazen profesyonellerin hizmetlerini zararlı olarak gördüklerini ve yaşamlarına izinsiz girilmesinden rahatsız olduklarını bilmelerine rağmen, onlara fayda sağlama ve onların refahını artırma yükümlülüğü bulunmaktadır. Dolayısıyla yararııık, bazı durumlarda müracaatçıların istemediği ya da onları kendi tercihleri dışındaki kararlara uymaya zorlamaktadır. Meydana gelen bu durum paternalizme yol açmaktadır. Dolayısıyla paternalizm; bir kişiyi zorlama, aldatma veya bilgilerini ifşa etme amacı gütmeksizin başkalarının iyiliği için isteklerinin veya eylemlerinin geçersiz kılınmasıdır (Linzer, 2002). Bassford (1982), paternalizmi şu şekilde açıklamaktadır: "Birisi, bir başkasına babacan davranarak o kişiyi ne yapacağını ya da ne ile karşılaşacağını seçmekten mahrum bırakırsa, bunu kendi iyiliği için yapar".

Paternalizm sosyal hizmette, müracaatçının rızası olmadan ona yardım etmeye çalışıldığında ortaya çıkar. Bu, müracaatçının onuruna ve bağımsızlığına bir hakaret olarak kabul edilir. Paternalizmin tüm tanımları, bireyin iyiliği için meşrulaştırılan zorlama veya müdahale unsurlarını içerir. Bu bağlamda Childress (1981), paternalizmin ilk bakışta yanlış olduğunu ve gerekçelendirilmesi gerektiğini iddia eder. Ancak paternalizm her zaman olumsuz olarak değerlendirilemez. Paternalizm algısı, şartlar, koşullar ve uygulanma şekline ve eylemin müracaatçının haysiyetine uygun olup olmadığına bağlı olarak değişir. Özetle, sosyal hizmet müdahalesinde özerklik, haysiyete saygı, yararlandırma ve paternalizmi ayıran ince çizgiler bulunmaktadır. Sosyal hizmet uzmanı, müdahaleleri seçerken söz konusu prensipleri göz önünde bulundurmaktadır. Ancak burada en kritik konulardan biri müracaatçının karar verme yetkinliği ve kapasitesinin yeterli olup olmadığıdır. Çünkü bazı durumlarda 
müracaatçıların karar verme yetisi güvenilir olmayabilir. Bu sebeple özellikle müracaatçının yaşlı bir birey olduğu durumlarda kişinin karar verme kapasitesi, doğru bir şekilde değerlendirilmelidir (Linzer, 2002).

Linzer etik konusunda son derece önemli olan ikilemi olgu örnekleri üzerinden açıklamıştır. İlk olgu şu şekilde aktarımaktadır: Evli bir çift olan A ve B, doktorları tarafından sosyal servise yönlendirilmiştir. Doktoru yaşlı kadının (B) artan kırılganlığı ve demansı konusunda endişelenmekte ve onun evde bakıma ihtiyaç duyduğunu düşünmektedir. A ve B iki odalı bahçeli bir apartmanda yaşamaktadır ve çocukları yoktur. Sosyal hizmet uzmanı eve gittiğinde 85 yaşındaki A'nın dağınık ve kirli olduğunu görür. Uzman, gözlemlerine dayanarak A'nın bilişsel açıdan zayıf olduğunu düşünür. 80 yaşındaki $B$ ise yaşadığı büyük bunalımdan dolayı ölmek istediğini bildirir. Apartman kirli ve kağıtlarla doludur. Çamaşırla dolu dolap idrar kokmaktadır. B, ayda bir kez çamaşırları yıkamaya gönderdiğini, arada bir de temizlikçi tuttuğunu söyler. B yürürken zorlanmakta eşyalara tutunarak yürümektedir. Ancak yine de evde kendileri için yemek yapabilmektedir. Burada ikilem şudur: Aile; olgu yönetimi, danışmanlık ve evde bakım hizmetlerine intiyacı olduğu halde bir değişiklik istememekte, para yardımı almayı reddetmektedir. Bu durumda; A ve B'nin özerkliği desteklenmeli midir? Güvenlik sorunları, seçtikleri yaşama haklarını ne zaman geçersiz kılabilir? (Linzer, 2002).

Linzer'in diğer bir olgu örneği ise şu şekildedir: $G$, birden fazla kronik hastalığı olan ve tekerlekli sandalyeye mahkûm olan 73 yaşında bir erkektir. Görünüşü dağınık ve kirlidir. İdrar ve alkol kokmaktadır. Uyuşturucu kullanımının çok yaygın olduğu bölgede yaşayan G, evine hırsız girdiği için polise başvurmuştur. Soygun olayından sonra G, başka bir mahallede yaşayan oğlu ile kalmaya başlamış, ancak alkol kullanan oğlu bir süre sonra G'yi evde istememiştir. G, evine dönmek ve hizmet almak konularında olumsuz yanıt vermektedir. Sosyal hizmet uzmanı bu olguda bilişsel yetkinliği olduğu halde G'ye hizmet vermek ya da onun özerkliğine saygı duymak noktasında ikilem yaşamaktadır (Linzer, 2004).

Evde bakım hizmetlerini reddeden yaşlılara özgü bu olgular, sosyal hizmet uzmanı için özerklik-haysiyet-fayda-paternalizm ikilemini ve yaşlıların karar verme kapasitesine ilişkin karmaşık meseleyi çağrıştırmaktadır. Sosyal hizmet değerleri arasında kendi kaderini tayin hakkının merkeziliği göz önüne alındığında, zayıf yaşlılar için desteklenecek özerklik hakkının derecesine ilişkin karar, sosyal hizmet uzmanları için sıkıntı yaratabilir (Linzer, 2002). 
Etik ikilem, evde bakım sağlama veya müracaatçının talebini kabul etme arasında gerçekleşmektedir. Dolayısıyla bu aşamada çatışma, özerkliğe ve haysiyete saygı göstermek ile faydalanmayı teşvik etmek ve paternalizme yol açmak arasında yaşanmaktadır. Sosyal hizmet uzmanı, A ve B ile çalışmaya devam ettikçe, çiftin geçmişi ve sağlığı ile ilgili veriler elde ettikçe, müracaatçıların karar verme kapasiteleri ve yeterliliklerine dair şüphe duymasına rağmen onların özerkliğini destekleme eğiliminde olmuştur. Sosyal hizmet uzmanı, bu olguda evde bakımı dayatmaya çalışmamış ancak müracaatçı özerkliği ile fayda arasında bir orta yol aramıştır. Uzman, müracaatçılar ile sağlık durumları artık kendi kendilerine yetemeyecekleri noktaya gelirse, ihtiyaçlarını karşılamak için evde bakım teklifini kabul edecekleri noktasında anlaşmıştır. Sonuç olarak, kııılgan yaşlıların özerklik haklarının geçersiz kılınması konusu evde bakımda öne çıkan, zorlu etik ikilemlerden biridir. Bu ikilem, özerklik ve haysiyete saygıyı; yararlandırma yükümlülüklerini ve paternalizmin gerekçelerini aynı zamanda yetkinin belirlenmesine dayanan müzakereleri kapsar. Çünkü müracaatçıların yetkinliği açıkça belirtilmediği için ilkenin uygulanmasının şaibeli olduğu bir durumda alınan karar, önü alınamayacak hatalara sebebiyet verebilmektedir (Linzer, 2002).

Illk olguda ise sosyal hizmet uzmanı, özerkliğe ve onura saygı duymayı seçmesine rağmen, seçilmeyen alternatif karşısında rahatsızlık ve suçluluk içinde olmaya devam edebilir. Görüldüğü üzere yararıılık, mevcut durumda özerklik ve onur kadar ağır olmadığı düşünülse de geçerli bir yaklaşım olmaya devam etmektedir. Moody ise müracaatçının özerkliğine saygı duymak yerine, zayıf yaşlılara hizmet vermenin, haysiyeti koruyan bir tür örtülü paternalizm getirdiğini öne sürmüştür (Moody, 1998). Bu bakım şeklinde kurumun, müracaatçıların, sağlık veya diğer durumlarındaki herhangi bir değişikliği anında öğrenebilmesi için müracaatçıları izlemeye devam etmesi gerekir. Müracaatçıların mevcut durumu değiştikçe, çelişen değerlerin ağırlı̆ı̆ ve dengesi değişebilir. Bazı durumlarda etik ikilemler zamanla kendiliğinden çözülebilir. Sosyal hizmet uzmanı, müracaatçıların fiziksel ve zihinsel durumları hakkında yeni bilgiler edindikçe, bir karardan diğerine yönelebilir (Linzer, 2002).

Çatışan değerler, eylemler, kurallar, ilkeler ve teoriler alınacak kararı zorlaştııı. Olgu, müdahaleyi reddeden yetişkin bir mağduru içerdiğinde ikilem daha da artmaktadır. Quinn, sosyal hizmet uzmanının yetişkin bir mağdurla çalışırken, müracaatçının müdahaleyi reddetme hakkına saygı göstermesi gerektiğini, güvenlik ve korumanın 
müracaatçının kendi kaderini tayin etme hakkına göre ikincil sırada olması gerektiğini iddia eder (Quınn, 1985). Etik ikilem bazen her iki ilkeyi de birleştiren bir sosyal hizmet uygulamasıyla çözülebilir ve böylece aralarında seçim yapmaya gerek kalmayabilir. Bu durumda yapılması gereken, müracaatçının kendi kaderini tayin hakkına saygı göstermek ve müracaatçının durumundaki değişiklikleri izlemektir. Yaşlı bireylerle gerçekleştirilen sosyal hizmet uygulamaları, kendi içinde zorluklar ve ikilemler barındırmaktadır. Yaşlılarla ilgili olgu süreçleri şunu göstermiştir ki, ilgili taraflar için kabul edilebilir uygulamaların bulunabileceği durumlarda, dayatılan kararlardan kaçınmakta fayda vardır. Sosyal hizmet uzmanının müracaatçıyı dinleyerek, kabul ederek ve iletişimi sürdürmeye teşvik ederek ilgilenme çabaları etik ikilemde olumlu bir çözüm elde etme konusunda başarılı olmuştur. Çünkü bu süreç; doğrudan intiyacı karşılamasa bile, müracaatçının dürüstlüğüne, terapötik ilişkiye girmeye hazır hissetmesine saygı gösterir (Linzer, 2004).

Örneklerden de anlaşılacağı gibi etik ikilemler bazen, zaman geçtikçe kendi kendilerine çözülebilmektedir. Dolayısıyla müracaatçının fiziksel ve zihinsel durumları hakkında yeni bilgiler elde edildikçe, sosyal hizmet uzmanının karar vermesi kolaylaşacaktır (Linzer, 2002).

\section{OLGU}

Ömer K. ve Aydın K., 2008 ve 2005 doğumlu iki kardeştir. Babaları tarafından sokakta zorla çalıştııımaları ve babaları tarafından şiddete maruz kaldıkları için 2004 doğumlu ablalarının yönlendirmesi ile emniyete başvurmuşlardır. Çocukların fiziksel görünümleri yaşları ile uyumludur. Akranları ile iyi ilişkiler kuran, duygu ve düşüncelerini iyi bir şekilde ifade edebilme becerisine sahip olan çocukların babalarına karşı güven duyguları zayıftır. Genel adli muayene raporunda çocuklarda ekimozlar ${ }^{6}$ tespit edilmiştir. Babanın tutarsız yanıtları ve diğer görüşmeler değerlendirildiğinde çocuklar için acil koruma tedbiri talep edilmiş ve kardeşlerin durumlarının değerlendirilmesi amacı ile görüşmeler sürdürülmüştür.

Mahmut K. ve eşi İnci K'nın biri kız üçü erkek olmak üzere toplam dört çocukları bulunmaktadır. Ailenin en büyük çocuğu Banu K. (2004 doğumlu), en küçük çocuğu

\footnotetext{
${ }^{6}$ Ekimoz: Cilt altı dokulara kanın sızması sonucu görülen morarma veya renk değişikliği olarak tanımlanır (Avşar \& Kaşıkçı, 2012).
} 
ise Oğuz K'dır (2014 doğumlu). Aile, apartman girişi ayrı olan 1+1 bir evde yaşamaktadır. Evin duvarlarının boyasının döküldüğü, evin hijyenik olmadığı, bir odada çok sayıda halının olduğu, koltukların üzerinde yer yataklarının bulunduğu, mutfaktaki beyaz eşyanın çok eski olan buzdolabı ve set üstü ocaktan oluştuğu, evin oldukça dağınık olduğu, evde ısıtma için bir adet elektrikli sobanın bulunduğu tespit edilmiştir. Ailenin daha önce kendisine ait olan evi, baba Mahmut K. aile üyelerine haber vermeksizin satmıştır, ev sahibine ödenecek kiranın gecikmesi ile gerçeğin ortaya çıktığı, Mahmut K.'nın, eşi İnci K.'nın ziynet eşyalarını çaldığı ve yerine sahte ziynet eşyaları bıraktığı öğrenilmiştir.

Anne İnci K. ile yapılan görüşme neticesinde; baba Mahmut K.'nın çalışmadığı, tüm aile üyelerine şiddet uyguladığı, 5 yı önce Şule isimli bir kadınla birlikte yaşadığı, kadının ve çocuklarının yine şiddet sebebi ile kaçtığı öğrenilmiştir. Mahmut K.'nın iki yıl önce kaçak telefon sattığı için bir yıl iki ay cezaevinde kaldığı ve sonrasında denetimli serbestlik kararı ile serbest bırakıldığı tespit edilmiştir. Cezaevinden çıktığında ailesinin yanına uğrayan Mahmut K. çocukların mendil satarak para kazandığını görünce daha sık eve uğramaya başlamış, çocuklar üzerinde sokakta çalışmaları için baskı kurmuş ve şiddet uygulamaya başlamıştır. Baba Mahmut K.'nın eve gelmediği zamanlar vardır. Bu dönemlerde başka bir kadınla yaşadığı aile üyeleri tarafından bilinmektedir.

Anne İnci K., iki çocuğunun kuruma yerleştirilmesinden sonra anneanne Naime A.'nın yanına sığınmıştır. Anneanne Naime A., baba Mahmut K.'nın fiziksel ve psikolojik şiddetine tanıklık ettiğini söylemiştir. Naime A., kızı ve torunlarını geçici süre ile kabul etse de ekonomik durumunun yetersiz olması nedeni ile uzun vadede bir çözüm sunamadığını ifade etmiştir.

Anne İnci K., görüşme talebini kabul etse de sonraki görüşmelere gerekçeler sunarak katılmamıştır. Abla Banu K., kurum ziyaretine kardeşini görmek için gittiğinde kendisi ile görüşme yapılmıştır. Banu K., Ömer K.'nın kurumu izinsiz terk edip yanlarına geldiğini, annesinin babası ile barıştığını söylemiştir. Banu K. babası ile ilk kez alışverişe gittiğini, bir süredir babasının evde şiddet uygulamadığını, kardeşlerini sokakta çalışmaya zorlamadığını ancak babasına tam olarak güvenemediğini ve kardeşleri ile yaşamak istediğini belirtmiştir. Banu K. ile görüşme sonrasında yapılan ev ziyaretinde daha çok ekonomik sıkıntılar ifade edilmiş hem anne hem babanın çocukları ile bir arada yaşamak istediği gözlenmiştir. Tüm çocukların anne ile arası 
iyidir ve Aydın K. dışındaki çocuklar aile yanında kalmayı tercih ettiklerini ifade etmişlerdir.

\section{Olguya Yönelik Etik Değerlendirme:}

Müracaatçının özerkliğini odak alma ve müracaatçıya fayda sağlama seçeneklerinin altyapısı sosyal hizmetin etik ilkeleriyle desteklendiğinden dolayı her iki seçenek de sağlam temellere dayanmaktadır. Yukarıdaki örnekte olduğu gibi bazı olgularda söz konusu seçenekler doğrultusunda verilecek kararlar, tamamen zıt yönleri gösterebilir. Sosyal hizmet uzmanı, eylemlerin olguya uygunluğunu göz önünde bulundurarak, hangi tarafın daha baskın geldiğine karar vermek ve bu doğrultuda uygulanacak müdahale planları arasında uzlaşmaya yer olup olmadığını belirlemek zorundadır. Linzer (2004), etik ikilem durumlarının bazen her iki etik değeri de kapsayan ve bütünleştiren bir sosyal hizmet ilkesi kullanılarak çözülebileceğini ve böylelikle iki seçenek arasında hangisinin uygulanması gerektiğine karar verme zorunluluğunun önüne geçilebileceğini savunur. Yukarıda verilen olgu örneğinde bütünleştirici ilke, müracaatçının kendi kaderini tayin hakkına saygıdır. Dolayısıyla Aydın K.'nın kurumda kalma; Banu K., ve Oğuz K'nın ailenin yanında kalma; İnci K.'nın ise eşiyle barışıp tekrar beraber yaşama tercihlerini bildirmeleri üzerine sosyal hizmet uzmanının yaptığı derin görüşmeler ve muhakemeler sonucu özerklik ilkesi ağır basmış ve bu doğrultuda müdahaleler uygulanmıştır. Ancak Ömer K.'nın aile yanında kalma talebi hemen gerçekleştirilmemiş, bu talebin yeniden değerlendirilmesi ve bu süreçte Ömer K.'nın başka bir kuruluşa naklinin sağlanmasına karar verilmiştir. Bu kararda yararlılık ilkesinin baskın geldiği görülmektedir.

Olguda uygulanan müdahaleler şu şekilde sıralanmaktadır:

- 2005 doğumlu Aydın K. hakkında 5395 sayılı Çocuk Koruma Kanununun 5/1-c bendi gereği "çocuğun bakımından sorumlu olan kimsenin herhangi bir nedenle görevini yerine getirmemesi halinde, çocuğun resmi veya özel bakım yurdu ya da koruyucu aile hizmetlerinden yararlandırılması veya bu kurumlara yerleştirilmesi” hükmü yer aldığından bakım tedbiri uygulanmasının (Çocuk Koruma Kanunu, 2005: 5/1-c),

- Örgün eğitim çağında olan, herhangi bir suç öyküsü bulunmayan, bağımlılık yapıcı madde kullanımı olmayan, kuruluş kurallarıyla uyumlu davranış 
sergileyen 2008 doğumlu Ömer K.'nın bireysel özelliklerine uygun bir kuruluşa naklinin gerçekleştirilmesinin,

- Yasal mevzuat çerçevesinde uygun görülen tarihlerde çocuğun ailesinin yanında izinli kalmasının,

- X kurumundan kaçak aranması devam eden 2008 doğumlu Ömer K.'nın belirtilen kuruluşa kabulü halinde $X$ kurumu müdürlüğü 7-12 Yaş İlk Kabul Müdahale ve Değerlendirme Birimi tarafından durumunun yeniden değerlendirilmesinin,

- Eğitimine devamının sağlanması amacıyla 2004 doğumlu Banu K.'nın 5395 Çocuk Koruma Kanununun 5/1-b bendi gereği eğitim tedbiriyle desteklenmesinin (Çocuk Koruma Kanunu, 2005: 5/1-b),

- 2004 doğumlu Banu K.'nın karşılaşabileceği sorun ve çatışmalarda uygun rehberliğin sağlanması, anne ve babanın hane içerisindeki problemlere yönelik uygun tutum geliştirmesinde yardımcı olunması, anne ve babanın çocuk yetiştirme ve çocuklarına yaklaşım konusunda bilinçlendirilmesi, aile öyküsü dikkate alınıp aile durumunun takip edilerek bu yönde rehberliğin sağlanması amacıyla 5395 sayılı Çocuk Koruma Kanunu'nun 5/1-a bendi gereği 2004 doğumlu Banu K. ve 2014 doğumlu Oğuz K. adına "K." ailesine danışmanlık tedbiri uygulanmasının (Çocuk Koruma Kanunu, 2005: 5/1-a),

- Ailenin gelir düzeyinin düşük olması, eğitime devam etmesinde yararlı olacağı düşünüldüğünden Sosyal ve Ekonomik Destek Hizmetleri Yönetmeliği'nin 6. maddesi (b) bendince uyarınca bir (1) yıl süreli olarak 2004 doğumlu Banu K. adına anne İnci K.'ya destek sağlanmasının uygun olacağı kanaatine varılmıştır(Sosyal ve Ekonomik Destek Hizmetleri Hakkında Yönetmelik, 2015: 6-b)

Çalışmada ele alınan olgunun başlangıç noktası en büyük toplumsal sorunların başında gelen çocuk istismarı/ihmali, çocuk iş̧̧iliği ve aile içi şiddettir. Dolayısıyla olgunun çok boyutlu karmaşık yapısı, üzerine düşünülmesi gereken bir dizi müdahale planını gerekli kılmaktadır.

Olgu değerlendirme süreci devam ederken, müracaatçılların aile dinamiklerinde yaşanan değişiklikler doğrultusunda, tercihlerini beyan etmeleri üzerine sosyal hizmet uzmanı, özerklik ve yararlıık arasında seçim yapmak durumunda kalmıştır. Bu noktada uzman, sosyal hizmetin bir diğer değeri olan kendi kaderini tayin hakkını referans 
alarak, ikilemin bütünleştirici ve kapsayıcı başka bir ilke yoluyla çözülmesini sağlamıştır.

Uygulanan sosyal hizmet müdahalesinde özerklik ilkesi baskındır. Ancak yararlıık ilkesi gereğince alınan kararlar da bulunmaktadır. Bu kararların bazı noktalarda paternalizme yol açtığı düşünülebilir. Ancak burada paternalizmi tümüyle olumsuz bir sonuç olarak değerlendirmek yanlış olacaktır. Çünkü paternalizm algısı; koşulların ve müdahale biçiminin, müracaatçının onuruna uygunluğuna göre değişebilir. Sosyal hizmet uzmanlarının, müracaatçılarına fayda sağlama ve refahlarını artırma sorumluluğu bulunmaktadır. Söz konusu olguda, müracaatçının karar verme kapasitesi ve yetkinliğinin belirlenmesi; ailede şiddet, istismar ve inmal sorunlarını kesin ve yoruma mahal vermeyecek şekilde sona erdiğinin tespit edilmesi için olgunun bir süre izlenmesi zorunludur. Bu süreçte durumunun tekrar değerlendirilmesi şartılla müracaatçının kuruma nakledilmesine karar verilmiştir. Dolayısıyla uzman, mesleki sorumluluklar gereğince yararlandırma idealine uygun hareket etmiş ancak gerekli koşulların sağlanması halinde müracaatçının talebinin tekrar değerlendirilmesini sağlamıştır.

Ele alınan olguda uzmanın tamamıyla yararlandırma idealine göre hareket ettiği senaryoda tüm müracaatçıların tercihleri göz ardı edilecek ve müracaatçılar, yapılacak müdahaleleri reddetmelerine rağmen buna zorunlu tutularak verimli olacağı şaibeli bir değişime sürüklenecektir. Ayrıca sosyal hizmet müdahalelerinde üzerinde sıkça durulan hususlardan olan uzman ve müracaatçı arasındaki fikir birliği sağlanamayacak ve bu durum, taraflar arasındaki terapötik ilişkinin oluşmasına engel olacak ya da sürdürülmesini güçleştirecektir. Öyle ki sosyal hizmette vurgulanan "kişiye rağmen müdahale gerçekleştirilemez" söylemi de bu noktada önemli bir referanstır.

Çalışmada aktarılan olgunun yönetiminde sosyal hizmet uzmanı, müracaatçıları dinleyerek, iletişim halinde olmaya teşvik ederek onları müdahale sürecine dahil etmiş; müracaatçıların kendi tercihlerini göz önünde bulundurarak, karar verme aşamasında sosyal hizmetin en temel ilkesinin rehberliğinde ilerlemiştir. Aynı zamanda müracaatçıların tercihlerinin değişebileceği intimalini de göz ardı etmeyerek, oluşabilecek riskleri erken teşhis etme amacıyla müdahaleye olgu izleme planını da eklemiştir. Dolayısıyla mevcut planda özerklik baskın gelse de her an eyleme geçmeye hazır, yararılıık sağlamaya ilişkin müdahale planı da devrede olduğundan, 
uygulanabilecek en verimli ve altyapısı sağlam olan yolun seçilmesine özen gösterildiğini söylemek mümkündür.

\section{SONUÇ}

Etik ilke ve değerler, sosyal hizmet uzmanlarına mesleki müdahalelerinde rehberlik etmeyi amaçlamaktadır. Bu ilke ve değerlerin birbirleri ile çatışması etik ikilemleri ortaya çıkarmaktadır. Etik ikilemler sosyal hizmette sıklıkla karşılaşılan durumların başında gelmekte ve bazı olguların çözümlenmesini zorlaştırmaktadır.

Sosyal hizmet uygulamalarında çatışan ilkeler, müracaatçının karar verme kapasitesi ve yetkinliğinden etkilenebilir. Özerklik ilkesinin gereği olarak müracaatçının karar verme becerisinin belirlenmesi, bir dizi gözlem ve dikkatli analiz gerektirir. Bu çalışmada olgu üzerinden değerlendirilen etik ikilem; özerklik ve yararlandırma ilkelerinin çatışmasına dayanmaktadır. Her iki ilkenin de sağlam bir altyapısı ve haklı sonuçları bulunmaktadır. Sosyal hizmet uzmanının derin muhakemeler sonrasında aldığı kararların çoğu müracaatçıların değişen yargıları çerçevesinde şekillenmiştir.

Sonuç olarak etik ikilem durumları, sosyal hizmet uzmanları için karmaşık etik muhakemeler barındıran süreçlerdir. Etik ikilemi değerlendirme ve çözme süreci eleştirel düşünme becerisini gerekli kılar. Bir olguya ilişkin müdahale planı belirlerken etik ilkeler doğrultusunda ilerlemek, içinde bulunulan koşullar çerçevesinde müracaatçılar için en doğru olan sonuçlara ulaşabilmek açısından oldukça önemlidir. Çatışma durumlarında çözüm odaklı yaklaşım, kanıta dayalı uygulamalar ve süpervizyon desteğinden yararlanılabilir. Bu yöntemler, etik muhakeme sürecinin daha sağlıklı ve sağlam temellere dayanarak yürütülmesine olanak tanır. Etik ikilemin çözümlenmesi, çatışan ilkelerin daha kapsayıcı ve yol gösterici başka bir ilke çatısında bütünleştirilmesi yoluyla sağlanabilir. Ayrıca kararlı yapıda olan ve çözülmesi mümkün görülmeyen bazı etik ikilem durumları da zamanla kendiliğinden çözülebilir.

\section{KAYNAKÇA}

Abrams, L. S., \& Moio, J. A. (2009). Critical Race Theory And The Cultural Competence Dilemma In Social Work Education. Journal of Social Work Education, 45(2), 245-261. 
Abramson, M. (1985). The Autonomy-Paternalism Dilemma In Social Work Practice.

Social Casework: The Journal of Contemporary Social Work, 387-393.

Avşar, G., \& Kaşıkçı, M. (2012). Subkütan Heparin Enjeksiyonlarında Ekimoz, Hematom ve Ağrıyı Önlemek İçin Nelere Dikkat Edilmeli? stanbul Üniversitesi Florence Nightingale Hemşirelik Yüksekokulu Dergisi, 20(3), 239-246.

Bassford, H. A. (1982). The Justification Of Medical Paternalism. Social Science \& Medicine, 16(6), 731-739.

Bauman, Z. (2007). Liquid Times: Living in an Age of Uncertainty. Cambridge: Polity Press.

Beauchamp, T. L., \& Childress, J. F. (2001). Principle of Biomedical Ethics (5 b.). New York: Oxford University Press .

Bernasconi, S. M. (2010). Human Rights - Facing Dilemmas Between Universalism And Pluralism/Contextualism. D. Zaviršek, B. Rommelspacher, \& S. StaubBernasconi (Dü) içinde, Ethıcal Dılemmas In Socıal Work: International Perspective. Ljubljana: Faculty of Social Work.

Childress, J. F. (1981). Priorities in Biomedical Ethics (1 b.). Philadelphia: Westminster John Knox Press.

Çiftçi, E. G., \& Gönen, E. (2011). Sosyal Hizmet Uygulamalarında Etik Karar Verme Süreci. Toplum ve Sosyal Hizmet, 22(2), 149-160.

Çocuk Koruma Kanunu. (2005).

https://www.mevzuat.gov.tr/MevzuatMetin/1.5.5395.pdf adresinden alındı

Erkoç, B., \& Lofti, S. (2021). Sosyal Hizmet Öğrencilerinin Psikolojik Sağlamlık Düzeylerinin Etik İkilem Karşısında Tutumlarına Etkisinin Tespit Edilmesine Yönelik Bir Araştırma. Yükseköğretim ve Bilim Dergisi, 11(2), 411-416.

Farberman, H. A., Fınch, S. J., \& Bergman, P. K. (1997, \& Stony Brook Suny; Volume 5, Number 1. Pages 101-111.). Confidentiality Vs. Mandated Reporting of Child Abuse: A Social Work Research Dilemma. Applied Behavioral Science Review, 5(1), 101-111.

Grossmanns, R. (2010). Justice Versus Care A Dilemma Of Ethics. D. Zaviršek, B. Rommelspacher, \& S. Staub-Bernasconi (Dü) içinde, Ethıcal Dılemmas In Social Work: International Perspective. Ljubljana: Faculty of Social Work.

Koç, S. Ç. (2015). Sosyal Hizmet Uzmanlarının Sorun Çözme Becerileri Üzerine Bir Araştırma. Yüksek Lisans Tezi. Ankara: Hacettepe Üniversitesi Sosyal Billimler Enstitüsü Sosyal Hizmet Anabilim Dalı.

Levy, C. S. (1976). Social Work Ethics. New York: Human Sciences Press. 
Linzer, N. (2002). An Ethical Dilemma in Home Care. Journal of Gerontological Work, 37(2), 23-34.

Linzer, N. (2004). An Ethical Dilemma İn Elder Abuse. Journal Of Gerontological Social Work, 43(2-3), 165-173.

Linzer, N., Conboy, A., \& Ain, E. (2003). Ethical Dilemmas of Israeli Social Workers. International Social Work, 46(1), 7-21.

Maynard, B. R. (2007). To EBP or Not To EBP?: Social Work's Dilemma with Evidence Based Practice. Fall 2007, 7, 5-15.

Moody, H. R. (1998). The Cost of Autonomy, the Price of Paternalism. Journal of Gerontological Social Work, 29(2-3), 111-127.

Moorhead, B., \& Johnson, S. (2010). An Ethical Practice Dilemma Involving A New Social Work Graduate: Implications For Social Work Practice. Practice: Social Work in Action, 22(1), 45-53.

Özateş, Ö. S. (2010). Sosyal Hizmet Etiğinin Felsefi Temelleri. Toplum ve Sosyal Hizmet, 21(1), 85-97.

Özkan, Y., \& Çiftçi, E. G. (2012). Sosyal Hizmette Kanıta Dayalı Uygulamalar: Sosyal Hizmet Eğitimi Açısından İrdelenmesi. Toplum ve Sosyal Hizmet, 23(1), 149160.

Quınn, M. J. (1985). Elder Abuse and Neglect: Raise New Dilemmas. Generations: The Journal of the Western Gerontological Society, 70(2), 22-25.

Reamer, F. G. (1997). Ethical standards in social work: The NASW Code of Ethics. R. L. Edwards (Dü.) içinde, Encyclopedia of Social Work (19 b., s. 113-123). Washington DC: NASW Press.

Sasson, S. (2008). Beneficence versus Respect for Autonomy. Journal of Gerontological Social Work, 33(1), 5-16.

Sosyal ve Ekonomik Destek Hizmetleri Hakkında Yönetmelik. (2015). https://www.resmigazete.gov.tr/eskiler/2015/03/20150303-3.htm adresinden alındı

Türer, C., \& Aydın, M. (2019). "Utilitarianism" ve "Pragmatism": Farklar Ortak Noktalar. FLSF Felsefe ve Sosyal Bilimler Dergisi(28), 121-149.

Zaviršek, D., Rommelspacher, B., \& Staub-Bernasconi, S. (Dü). (2010). Ethıcal Dılemmas In Socıal Work: International Perspective. Ljubljana: Faculty Of Social Work. 